Relations industrielles

Industrial Relations

\title{
The Communist Manifesto
}

\section{Egbert Munzer}

Volume 3, numéro 7, mars 1948

URI : https://id.erudit.org/iderudit/1023605ar

DOI : https://doi.org/10.7202/1023605ar

Aller au sommaire du numéro

Éditeur(s)

Département des relations industrielles de l'Université Laval

ISSN

0034-379X (imprimé)

1703-8138 (numérique)

Découvrir la revue

Citer cet article

Munzer, E. (1948). The Communist Manifesto. Relations industrielles / Industrial Relations, 3(7), 103-106. https://doi.org/10.7202/1023605ar

Tous droits réservés @ C Département des relations industrielles de l’Université Laval, 1948
Ce document est protégé par la loi sur le droit d'auteur. L’utilisation des services d'Érudit (y compris la reproduction) est assujettie à sa politique d'utilisation que vous pouvez consulter en ligne.

https://apropos.erudit.org/fr/usagers/politique-dutilisation/ 
ment les pays industrialisés, tels que l'Angleterre, où l'on pourrait trouver quelque ressemblance avec le système des deux classes de Marx et sur laquelle Marx s'est surtout fondé pour élaborer sa doctrine de la révolution.

D'un autre côté, les véritables révolutions sociales ont lieu dans les pays agraires de l'Europe orientale et de l'Asie. Pour ces pays, le Manifeste ne peut constituer une philosophie de l'histoire possédant même un degré modéré de précision; il peut être tout au plus une lumière quasi-religieuse et plutôt diffuse pouvant servir à l'établissement dun minimum de justice sociale.

Dans ces pays, les idées de Marx sont maintenant appliquées pour justifier une certaine sorte de capitalisme d'Etat, et pour les développer dans le sens du plan industriel établi par l'Europe occidentale et les Etats-Unis. Et pour couronner cette montagne d'inconsistence : en Russie, et dans tout le monde slave, le communisine se transforme de plus en plus en un nationalisme panslaviste violent qui doit faire frémir les restes de Marx dans son tombeau.

\section{THE COMMUNIST MANIFESTO}

\section{Egbert MUNZER}

Exactly a century ago today, Marx and Engels published in London, in the German language, the «Manifesto of the Communist Party». It was February 1848, and a few days after the publication of the «Manifesto», the revolution broke out in Paris.

In Summer 1847 a group of craftsmen, mostly Germans, held the first congress of the « Communist League » in London. Engels attended the congress, and it was he who proposed to draft a programme for a future congress of the «League». He composed a so-called catechism of twenty-five questions which he and Marx submitted to the second congress of the «League » in November 1847. This second congress charged Marx and Engels to draft a «Manifesto » on the basis of Engels' 25 points. Marx composed, during the winter-months $1847 / 48$, the Manifesto. It was to become one of the most-spoken-of documents of the century.

The Manifesto is divided into four parts. The first contains a «précis » of history as Marx saw it. History, to him, is the history of class-war, of the incessant contest between two strata of human society, a ruling and a subjected class. For a thousand years, the feudal class dominated European society and history. In the 17th and 18th century, first in England, then in France, the feudal class was overcome by the bourgeoisie. The bourgeoisie unleashed « powerful and colossal productive forces » and changed the face of the world. But these forces «have now grown to a point where they are no longer compatible with bourgeois property relations and bourgeois supremacy » as a ruling class. The new revolutionary class is the industrial workers, the proletariat. It will take over, by way of revolution, the property of the bourgeoisie and its political domination, and end the exploitation of man by man through the collectivization of all means of production; and thus restore social harmony forever. The second part of the Manifesto gives a few details of the policy of the new «Communist Party 》. It is the most progressive and activist section of the working class of all countries. Its main aim is the promotion of revolutions which alone will end bourgeois domination, establish the proletariat as the new ruling stratum, and finally abolish the State altogether. The third part contains a criticism of other forms of socialism, which are lumped together as being either insincere or utopian. The last part is some kind of epilogue on the relations of the communists to other revolutionaries and essentially a continuation of the polemic of the third section.

As to exterior form, material content and lo. gical method, the Manifesto is not without precedent. Its form is that of religious incantation and admonition rather than of scientific analysis. Its psalmodic cadences reveal the psychological residue of Old Testament and Calvinist selfrighteousness and clamour for justice. That is, subconscious religious forces in Marx and Engels are used for political purposes and perverted towards non-religious or a-religious ends. The contents of the Manifesto were « in the air» since the French Revolution which had brought some kind of political freedom but had failed to create social and economic equality. Babeuf, with his « Conspiration des Egaux», Fourier and Owen with their ideas of a rather idyllic communism, Proud- 
hon and his identification of economic with historical laws, and Blanqui and others with their class-interpretation of history, all these and many others could be quoted with a view to reducing Marx' claim to originality and to putting him on a more modest pedestal than his successors would like to reserve for him. Finally, the historical method applied in the Manifesto is clearly that of Hegel: history as the battlefield of dialectics, of thesis, antithesis and synthesis - only that the classes, groups of living beings, take the place of the semi-divine ideas of the Delphic German Professor and praeceptor mundi. But even if ample deductions have been made from Marx' claim to creativeness: the great effect of the Manifesto can only be denied by those who like to close their eyes to social and historical reality.

During the century of its promulgation, the Manifesto has been tested against the background of historical evolution, and its intrinsic worth can to-day be gauged with some accuracy. But before we attempt such appreciation, we have to pass brief judgment on the basic idea underlying the Manifesto.

The idea that history is exclusively or even principally determined by the antagonism of, and war between, social classes is, of course, inacceptable to the Christian mind and, for that matter, to religious thought in general. This idea amounts to a total secularization of history, leaves no place for forces transcendent to the visible historical process, and is actually no more than a peculiar form of atheism. It contradicts religious ethics for which war between classes and class-hatred are symptoms of collective moral disease rather than the normal and regular forces which produce history.

It may be surprising that such an a-religious doctrine of history could influence large parts of mankind, and influence it more than any other nonChristian philosophy. But it is precisely the pseudo-religious character of the Manifesto (and of the subsequent work of Marx and Engels) which has generated this strong effect. It deeply appeals to the religious sentiments of men for purposes and ends which are no longer genuinely religious. In Marx especially, we find a strange blend between a social-economic scientist and a prophet or charismatic leader, though of a strongly secularized «genre ». We may even go so far as to call him the « Jeremiah of the 19th Century 》, with his violent denunciation of capitalist exploitation, his sermon-like admonitions to a dark and rotten world and the prediction of a Golden Age when all antagonisms will be resolved. In Marx and to a similar extent in Engels - subconscious religious forces especially those of the Old Testament, were fermenting and they gave final form to their main ideas: the proletariat represents the Chosen People; the capitalists are the Gentiles who, as did the Egyptians, Babylonians and Assyrians, oppress the Selected Race; the coming revolution will be the Day of Judgment when the chosen people will finally triumph over the inequities and vicissitudes of this world. Heaven drawn down to earth; the Kingdom of God here and now; secularization of religious sentiments and aims this is in the last resort the characteristic note of Marx' predictions and the justification of revolutionary activity.

And it is this substitute religion, not Marx' scientific analyses, which has captivated the generations since 1848. This is a strange fact from which we can draw here, at least, one principal conclusion: that it can be only religion of a genuine nature, and not science, which will ultimately overcome the religious aberration of historic materialism.

While we have to repudiate the philosophy of history underlying the Manifesto - and its sequel, modern communism, - we have to admit the partial truths which the Manifesto, similar to religious heresies, contain. The existence of social tensions cannot be denied; or else, social revolutions would be unimaginable. At certain epochs, religious and cultural creations will determine history, and religious strife will engender the cataclysms in human society. At other epochs, economic and social forces will surpass religious and spiritual values in their historical significance. It may be even true that in modern history economic forces tend continually to surpass others in their historical significance. But this neither means that it has always been so, nor that it will always remain so in the future.

That the «Manifesto 》 itself is a historical creation subject to historic relativity becomes evident when we now put the «Manifesto » to test by briefly viewing it against a century of social experience. There are, in the main, two oversimplifications - essential for the consistency of Marx' whole philosophy - which do not meet the historical test: the contention that there have always been two classes, always warring each other; and Marx' insistence upon the development from feu- 
dalism via the necessary stage of bourgeois capitalism to the proleterian paradise.

The first simplification can be explained by Marx' preoccupation with French and especially English conditions. In both countries - but only in them - feudalism had been removed by revolutions; in England, moreover, a peasantry scarcely existed any longer, so that workers and bourgeois capitalists seemed to form the two essential strata of society. But in France a peasantry of considerable strength existed, and the same was - and is - true of all other continental countries, to say nothing of non-European nations. Marx was prepared to admit the existence of a petite-bourgeoisie which would oscillate between the capitalists and the workers. Yet, this concession is hardly sufficient. The history of the century 1848-1948 has shown that men, unless coerced for a brief time, refuse to be herded into the two pens which Marx' solicitude provided for their well-being and their compliance with Hegelian schemes. Men insist on greater variety. Modern research, e.g. that of the eminent Italian savant Mosca, has shown that there is a ruling class - and not even this class is economically homogeneous - and a ruled mass, but the latter is quite normally split up into a number of «couches» (strata).

The question of the peasant constituted the first great lacuna of the «Manifesto ». Meanwhile, society has tended even to stratify further: e.g. modern officialdom in the super-bureaucratized European countries and in Russia has become a stratum which tends to replace the feudal class of old.

It is well known that Lenin, in 1903, worked out a new scheme under which the proletariat, scarcely existing in Russia where 80 percent of the populace then were peasants, had to seize power in cooperation with the peasantry and to establish a «democratic dictatorship 》 of workers and peasants. But the actual evolution of the Russian Revolution has meanwhile demonstrated that this amalgamation could only lead to the wilful proletarisation of the peasants who have by now become workers of «grain factories 》 called Kolkhoz and Sovkhoz. Of the scheme of social history in the Marxian sense nothing is left.

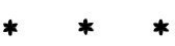

The other great shortcoming of Marx' view of the historico-social development is closely related to the assumption of the two-class-cycle. According to Marx' scheme, - and to common sense - the proletariat can only seize power when it exists, and it can only exist as the result of capitalistic development and the corresponding formation of a bourgeoisie as the ruling political class. But this capitalist-bourgeois class may either - as in the Slav world - not exist at all or it may be incapable or unwilling to make its own revolution - as in Germany until and even after 1918. In both cases the Marxian scheme does not fit. Marx never adjusted his doctrine to these facts (\& all the worse for the facts », his philosophical father Hegel would have said). In 1859, in the Preface to the «Critique of Political Economy », Marx reiterated: « No social form perishes until all the productive forces for which it provides scope have been developed. » It was only towards the end of his life that he admitted - as party leader and against the grain of his «science» - that a peasant country such as Russia may have the chance of achieving the social revolution without passing through the capitalist-bourgeois phase. Thus he wrote in the preface to a Russian translation of the « Manifesto 》 published in 1882: «If the Russian Revolution is the signal for a workers' revolution in the West so that these complement each other, then the Russian system of Communal Ownership (obstchina) can serve as the starting point for a Communist development. » The Bolshevist Revolution did not become the «signal» for a general workers' revolution, but it introduced communism in Russia. And it did so in flagrant contradiction to the revolutionary analysis of the «Manifesto». Once more, it was Lenin and his Bolshevist collaborators who «creatively 》 developed Marxism to the extent that nothing was left of the Manifesto but a frame, totally empty as far as Russia is concerned, and poorly filled as far as Western countries are at stake.

It is well known that the division between the Bolsheviks and the Mensheviks occurred, at the famous London Congress of 1903, over the interpretation of the Manifesto and the subsequent elaboration of Marx' doctrine of history. The Mensheviks, led by the theoretical lumen Plekhanoff, insisting on the Marxist analysis, regarded the creation of a powerful capitalist industry and of a bourgeois régime in Russia as the necessary precondition of the future Proletarian Revolution. The Bolsheviks differed, and Lenin elaborated the « New Testament 》 of Communism along the lines mentioned above. The rather startling result is that Marx, though the first patron saint of Russian communism, must be considered to be a Menshevik, not an orthodox «Marxist»; and this applies to an even greater measure to Engels. It is more than likely that their Russian disciples would have 
«purged» them, under the pretext of «treason against Marxism », had not a merciful death in Victorian England saved them long ago from undesired martyrdom.

These two main discrepancies between the philosophy of the «Manifesto» and sucial reality cannot but gravely affect the strength of the main foundation upon which Marx' house is built. The Marx of the «Manifesto » has not the slightest doubt that the seizure of political power by the proletariat will be a revolutionary act. Later in his life, however, Marx himself no longer believed in this article of faith. He admitted that in certain advanced countries the victory of the proletariat may be achieved without revolutionary violence. But what does «victory of the proletariat » under these circumstances mean ? It can only signify that nembers of the proletariat will gradually ascend and infiltrate into the ruling stratum and obtain a share in government equal to the social importance of the industrial working class. This, once more, is only common sense; it would have needed no Karl Marx to show it. All analysts of human society, from Aristotle to Mosca, Sorel and Pareto, are united in this truth.

Indeed in the whole Western World, the mutual absorption of ruling class and working masses appears now to be under way «without revolutionary violence ». And it is rather disconcerting for the Marxists to observe that these are precisely the industrialized countries, such as England, where one could find some resemblance to the two-class-system of Marx and for which Marx doctrine of revolution was coined in the first place. The real social revolutions, on the other side, are taking place in the agrarian countries of the European East and of Asia. For them the «Manifesto » cannot mean a philosophy of history of an even moderate degree of precision, but at the best a quasi-religious and rather vague «fanal» to establish a minimum of social justice. In these countries Marx' ideas are now being applied to justify some sort of state-capitalism and to develop them according to the industrial pattern set by Western Europe and America. And to crown this mountain of inconsistency: in Russia and the whole Slav world, Communism is increasingly transformed into a violent panslavist nationalism which would only make Marx turn in his grave.

\section{UNITÉ SYNDICALE ET CARTELS INTERSYNDICAUX}

\section{Jean-Pierre DESPRES}

La reconnaissance du principe de la liberté syndicale est consacrée par la législation du travail aussi bien que par l'évolution des relations industrielles. La liberté syndicale implique le droit pour le salarié d'adhérer à une organisation de son choix. En principe, sauf dans certains cas précis, elle implique également le droit de n'adhérer à aucune organisation. "La divergence iảéologique, au sein des sociétés modernes, déclare une résolution de la Confédération internationale des syndicats chrétiens, implique des conceptions différentes au sujet de la vie présente et future, des droits et des devoirs personnels, familiaux, professionnels et sociaux. » C'est pourquoi un travailleur adhèrera à telle organisation syndicale de préférence à telle autre. Il en résulte plusieurs groupements syndicaux dans un même pays, par suite de cette divergence idéologique entre les divers groupes de salariés. En d'autres termes, le pluralisme syndical est la conséquence logique du principe de la liberté syndicale. Est-ce un mal, ou plus exactement un obstacle au développement du syndicalisme considéré dans son ensemble? Nier le droit au pluralisme syndical équivaut à s'attaquer à la liberté syndicale elle-même et conférer, en fait, une orientation totalitaire à l'action syndicale.

Il ne s'agit pas de nier les avantages de l'unité syndicale ou de fermer les yeux sur les inconvénients réels du pluralisme syndical. La réalisation de l'unité syndicale et le développement du pluralisme syndical résultent de circonstances qui varient selon les pays. Au Royaume-Uni, par exemple, le problème du pluralisme syndical ne s'est pas posé jusqu'à présent. 'Il en est différemment des Etats-Unis, du Canada, de la France, de ia Belgique, de la Suisse, etc., où le pluralisme syndical est la règle. A moins de verser dans le t'talitarisme, on ne saurait, en principe et en fait, contester la reconnaissance du pluralisme syndical.

$\mathrm{Ne}$ vaudrait-il pas mieux pour la classe ouvrière n'avoir qu'une seule organisation centrale dans chaque pays et une seule organisation sur le plan international ? L'unité syndicale ne confèrerait-elle pas une influence plus considérable auprès des pouvoirs publics et du patronat ? La ré- 